\title{
In Vitro Assessment of the Impact of Nickel on the Viability and Steroidogenesis in the Human Adrenocortical Carcinoma (NCI-H295R) Cell Line
}

\author{
Norbert LUKAC ${ }^{1}$, Zsolt FORGACS ${ }^{2}$, Hana DURANOVA ${ }^{3}$, Tomas JAMBOR ${ }^{1}$, Jirina \\ ZEMANOVA ${ }^{1}$, Peter MASSANYI ${ }^{1}$, Barbara TOMBARKIEWICZ ${ }^{4}$, Shubhadeep \\ ROYCHOUDHURY ${ }^{5}$, Zuzana KNAZICKA ${ }^{6}$
}

${ }^{1}$ Department of Animal Physiology, Faculty of Biotechnology and Food Sciences, Slovak University of Agriculture in Nitra, Nitra, Slovak Republic, ${ }^{2}$ Independent Researcher, Budapest, Hungary, ${ }^{3}$ AgroBioTech Research Centre, Slovak University of Agriculture in Nitra, Slovak Republic, ${ }^{4}$ Department of Zoology and Animal Welfare, Faculty of Animal Sciences, University of Agriculture in Krakow, Krakow, Poland, ${ }^{5}$ Department of Life Science and Bioinformatics, Assam University, Silchar, India, ${ }^{6}$ Faculty of Biotechnology and Food Sciences, Slovak University of Agriculture in Nitra, Nitra, Slovak Republic

Received February 14, 2020

Accepted July 8, 2020

Epub Ahead of Print September 9, 2020

\section{Summary}

Nickel is a ubiquitous environmental pollutant, which has various effects on reproductive endocrinology. In this study, human adrenocortical carcinoma (NCI-H295R) cell line was used as an in vitro biological model to study the effect of nickel chloride $\left(\mathrm{NiCl}_{2}\right)$ on the viability and steroidogenesis. The cells were exposed to different concentrations (3.90; 7.80; 15.60; 31.20; $62.50 ; 125 ; 250$ and $500 \mu \mathrm{M}$ ) of $\mathrm{NiCl}_{2}$ and compared with control group (culture medium without $\mathrm{NiCl}_{2}$ ). The cell viability was measured by the metabolic activity assay. Production of sexual steroid hormones was quantified by enzyme linked immunosorbent assay. Following $48 \mathrm{~h}$ culture of the cells in the presence of $\mathrm{NiCl}_{2}$ a dose-dependent depletion of progesterone release was observed even at the lower concentrations. In fact, lower levels of progesterone were detected in groups with higher doses $(\geq 125 \mu \mathrm{M})$ of $\mathrm{NiCl}_{2}(\mathrm{P}<0.01)$, which also elicited cytotoxic action. A more prominent decrease in testosterone production $(P<0.01)$ was also noted in comparison to that of progesterone. On the other hand, the release of $17 \beta$-estradiol was substantially increased at low concentrations (3.90 to $62.50 \mu \mathrm{M})$ of $\mathrm{NiCl}_{2}$. The cell viability remained relatively unaltered up to $125 \mu \mathrm{M}(\mathrm{P}>0.05)$ and slightly decreased from $250 \mu \mathrm{M}$ of $\mathrm{NiCl}_{2}(\mathrm{P}<0.05)$. Our results indicate endocrine disruptive effect of $\mathrm{NiCl}_{2}$ on the release of progesterone and testosterone in the $\mathrm{NCI}-\mathrm{H} 295 \mathrm{R}$ cell line.
\end{abstract}

Although no detrimental effect of $\mathrm{NiCl}_{2}(\leq 62.50 \mu \mathrm{M})$ could be found on $17 \beta$-estradiol production, its toxicity may reflect at other points of the steroidogenic pathway.

\section{Key words}

Nickel chloride - Sexual steroid hormones - Cell viability • NCI-H295R cell line $\bullet$ Endocrine disruption

\section{Corresponding author}

H. Duranova, AgroBioTech Research Centre, Slovak University of Agriculture in Nitra, Tr. Andreja Hlinku 2, 94976 Nitra, Slovak Republic. E-mail: hana.duranova@uniag.sk

\section{Introduction}

Several environmental contaminants are recognized as endocrine disruptors (EDs), which may adversely affect the reproductive functions of humans, as well as wildlife species (Kabir et al. 2015, Vitku et al. 2015, Yang et al. 2015, Roychoudhury et al. 2016, Kolatorova et al. 2017, Jambor et al. 2018, Jambor et al. 2019). This heterogeneous group of exogenous substances has the ability to alter functions of the endocrine system with a subsequent negative impact on 
the cellular behaviour and health in an intact organism. Endocrine disruptors may be found in a variety of products, such as pesticides, household items, cosmetics or plastic packaging. It is likely that some EDs are structural analogues of steroids, having similar effects as true hormones, high levels of which may have disproportionate consequences (Sanderson 2006, Svechnikov et al. 2010). They can strongly affect reproductive and endocrine functions in several ways (Andersen et al. 2002), either by directly affecting the hormone production through interaction with the appropriate enzymes, or through interfering with their transport to target organs to alter natural hormone metabolism or even to inactivate the function of steroidogenesis regulatory proteins (e.g. Steroidogenic Acute Regulatory - StAR) (Sanderson and van den Berg 2003).

Nickel (Ni) is a widely distributed metal that is industrially applied in various mineral forms ( $\mathrm{Lu}$ et al. 2005). Dusts from volcanic emissions, the weathering of rocks and soils, biological cycles and solubilisation of Ni compounds from soils (Sunderman 2004) represent the main natural sources of atmospheric (7.0-12.0 ng of $\mathrm{Ni} / \mathrm{m}^{3}$ of air; $150 \mathrm{ng}$ of $\mathrm{Ni} / \mathrm{m}^{3}$ of air near point sources) and aqueous (3-10 $\mu \mathrm{g}$ of $\mathrm{Ni} / \mathrm{l}$ of water in surface water and groundwater) $\mathrm{Ni}$ (ATSDR 2005). Anthropogenic sources of Ni pollution include mining, smelting and refining activities, burning of fossil fuels, sewage incineration and plastic production ( $\mathrm{Yu}$ 2005). The major source of exposure to Ni for the general population is the food chain (Pandey and Srivastava 2000, Llamas and Sanz 2008). It usually enters the body via food and water consumption, although inhalation exposure in occupational settings is the primary route for Ni-induced toxicity (Ankel-Fuchs and Thauer 1988). Based on the average levels of $\mathrm{Ni}$ consumption through water (4.0-8.6 $\mu \mathrm{g} / \mathrm{day})$ and food (69.0-162.0 $\mu \mathrm{g} / \mathrm{day})$, the daily per oral intake of the metal was estimated to be $0.001-0.0024 \mathrm{mg} / \mathrm{kg} / \mathrm{day}$ for an average adult human being weighing $70 \mathrm{~kg}$ (ATSDR 2005). Another source of non-occupational exposure to $\mathrm{Ni}$ is tobacco smoking, and each cigarette is estimated to contain 1.1-3.1 $\mu \mathrm{g}$ of Ni (Cempel and Nikel 2006).

Although $\mathrm{Ni}$ is considered to be an essential micronutrient (Eisler 1998), it has a number of effects in the cell (Das 2009). It plays an important role in DNA, RNA and protein structure and/or function (Pandey and Srivastava 2000). Nickel also serves as a cofactor or a structural component of several metalloenzymes
(Przybyla et al. 1992). Deficiency is rare due to a low level of requirement, and relatively high availability in the diet, but experiments have shown that at cellular levels $\mathrm{Ni}$ deprivation may result in changes in the membrane properties and other structures (Das and Dasgupta 1997, Das 2009). On the contrary, high quantity of Ni is injurious for animal and human health (Pandey et al. 1999, Pandey and Srivastava 2000). More recently, several reports have showed that $\mathrm{Ni}$ is able to induce toxicological, physiological and histopathological alterations in a number of animal species (Pane et al. 2003, Bersenyi et al. 2004, Brix et al. 2004, Gupta et al. 2006, Krockova et al. 2011, Lukac et al. 2011). Soluble $\mathrm{Ni}$ compounds are likely to be human carcinogens (Costa 1991, Costa et al. 2005), and toxic and/or carcinogenic effects of such Ni compounds may be associated with Ni-mediated oxidative damage to DNA, proteins and inhibition of cellular antioxidant defences (Rodriguez et al. 1996). There is sufficient evidence that $\mathrm{Ni}$ ions $\left(\mathrm{Ni}^{2+}\right)$ have potential toxic effects on the reproductive system (Das and Dasgupta 2000). Animal studies referred to the negative effects of $\mathrm{Ni}^{2+}$ on the structure and function of testis, seminal vesicles, prostate gland (Pandey et al. 1999, Forgacs et al. 2001, Massanyi et al. 2003, Massanyi et al. 2007, Zemanova et al. 2007), and spermatozoa concentration as well as motility (Das and Dasgupta 2000, Lukac et al. 2011). Nickel salts are also capable of inducing morphological changes such as, degeneration of testicular germinal epithelium (Benson et al. 1988, Pandey et al. 1999), testicular sarcomas as well as functional disorders including inhibition of spermatogenesis (Mathur et al. 1977, Yokio et al. 2003) and steroidogenesis (Das and Dasgupta 2002, Krockova et al. 2011). Such negative effects may ultimately lead to sterility (Massanyi et al. 2007).

Steroidogenesis can be tested using a number of cell lines or primary culture with gonadal tissue, but the most widely used assay utilizes a human adrenocortical carcinoma (NCI-H295R) cell line. Such in vitro steroidogenesis screening assays are used to examine the impact of endocrine active chemicals/substances (EACs) capable of altering steroid biosynthesis (Ding et al. 2007, Fialkova et al. 2018). Progesterone, testosterone and estradiol are the main steroid hormones that play essential roles during the regulation of reproduction in vertebrates and are also involved in numerous other processes related to development and growth (Hecker and Giesy 2008). The present study investigated the effects of nickel chloride $\left(\mathrm{NiCl}_{2}\right)$ on the viability and steroidogenesis of 
the NCI-H295R cell line. Specifically, we examined the dose-dependent changes of $\mathrm{NiCl}_{2}$ as a potential endocrine disruptor in relation to the release of progesterone, testosterone and 17 $\beta$-estradiol by NCI-H295R cell line in vitro. The NCI-H295R cell line was derived from H295 cells, which were established from a primary hormonally active adrenocortical carcinoma (Gazdar et al. 1990, Rainey et al. 2004). This cell line has physiological characteristics of zonally undifferentiated human fetal adrenal cells (Staels et al. 1993, Harvey and Everett 2003), and represent an unique in vitro model system having the ability to produce all of the steroid hormones found in the adult adrenal cortex and the gonads, allowing testing the effects on both corticosteroid synthesis together with the production of sexual steroid hormones (Gazdar et al. 1990). Another advantage of the $\mathrm{H} 295 \mathrm{R}$ cell bioassay is that it can be used to evaluate the enzymatic activities of steroidogenic genes (Hilscherova et al. 2004). In fact, the NCI-H295R Steroidogenesis Assay has been included in the Tier1 Screening Battery of the United States Environmental Protection Agency's (EPA) Endocrine Disruptor Screening Program (EDSP). The test guideline of the H295R Steroidogenesis Assay (TG 456) has been further validated by the Organization for Economic Cooperation and Development (OECD 2011).

\section{Materials and Methods}

\section{Cell culture}

The NCI-H295R cell line was obtained from the American Type Culture Collection (ATCC, Manassas, VA, USA). The cells were cultured in a Good Laboratory Practice (GLP) certified laboratory (National Institute of Chemical Safety, Budapest, Hungary; OGYI/317629/2010) according to previously established and specifically validated protocols (Hilscherova et al. 2004, Zhang et al. 2005, Hecker et al. 2006, Hecker and Giesy 2008, OECD 2011).

After initiation of the NCI-H295R culture from the original ATCC batch, cells were cultured for five passages and these cells were split and frozen down in liquid nitrogen $\left(-196^{\circ} \mathrm{C}\right)$. The cells for the experiments were cultured for a minimum of five additional passages using new NCI-H295R batches from frozen stocks prior to initiation of the exposure studies. The cells were grown in $75 \mathrm{~cm}^{2}$ plastic cell culture flasks (TPP Techno Plastic Products AG, Switzerland) in an incubator under standard conditions $\left(37^{\circ} \mathrm{C}\right.$ and $5.0 \% \quad \mathrm{CO}_{2} \quad$ atmosphere). Subsequently, the cells were grown in a $1: 1$ mixture of Dulbecco's Modified Eagle's Medium and Ham's F-12 Nutrient mixture (DMEM/F12; Sigma-Aldrich, St. Louis, MO, USA) supplemented with $1.2 \mathrm{~g} / 1 \mathrm{NaHCO}_{3}$ (SigmaAldrich, St. Louis, MO, USA), $5.0 \mathrm{ml} / 1$ of ITS+Premix (BD Bioscience, San Jose, CA, USA) and $12.5 \mathrm{ml} / 1$ of BD Nu-Serum (BD Bioscience, San Jose, CA, USA). The medium was changed 2-3 times per week and cells were detached from flasks for sub-culturing using sterile $0.25 \%$ trypsin-EDTA (Sigma-Aldrich, St. Louis, MO, USA). After trypsinization, cells were plated at the appropriate density to obtain $90-100 \%$ confluency. Cell density was determined using a hemocytometer (Fig. 1) and adjusted with culture medium to a final concentration of 300000 cells $/ \mathrm{ml}$. The cell suspensions were plated (with final volume of $1.0 \mathrm{ml} /$ well) into sterile plastic 24-well plates (TPP, Grainer, Germany) for estimation of sexual steroid hormones (50-60\% confluency of cells). For cytotoxicity evaluation, the cells (100 $\mu \mathrm{l} /$ well) were seeded into 96-well plates (MTP, Grainer, Germany). The seeded plates were incubated at $37{ }^{\circ} \mathrm{C}$ and $5.0 \% \mathrm{CO}_{2}$ atmosphere for $24 \mathrm{~h}$ to allow the cells to attach to the wells (Knazicka et al. 2013).

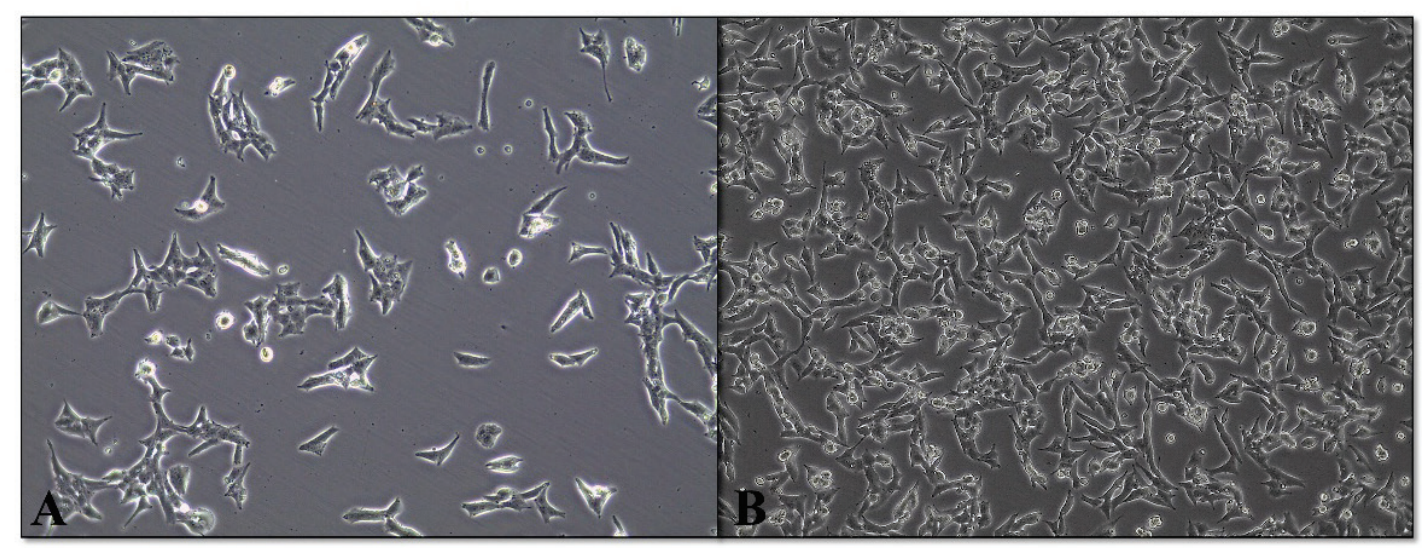

Fig. 1. Monolayer of human adrenocortical carcinoma (NCI-H295R) cell line. (A) low density; (B) high density (magnification 100x). 


\section{In vitro exposure}

After $24 \mathrm{~h}$ attachment period, the cell culture medium was removed from the plates and replaced with a new medium supplemented with $3.90 ; 7.80 ; 15.60$; $31.20 ; 62.50 ; 125 ; 250$ and $500 \mu \mathrm{M}$ nickel chloride $\left(\mathrm{NiCl}_{2} ; \geq 98 \%\right.$; Sigma-Aldrich, St. Louis, MO, USA), respectively. Cell cultures were set in 24 and 96-well plates (MTP, Grainer, Germany). Following treatment, the cells were maintained for $48 \mathrm{~h}$. The experimental groups A-H (exposed to different concentrations of $\mathrm{NiCl}_{2}$ ) with control group (Ctrl) (culture medium without $\mathrm{NiCl}_{2}$ ) were compared.

\section{Cell viability}

The viability of the cells exposed to $\mathrm{NiCl}_{2}$ was evaluated by the metabolic activity (MTT) assay (Mosmann 1983). This colorimetric assay measures the conversion of a yellow tetrazolium salt [3-(4,5dimethylthiazol-2-yl)-2,5-diphenyltetrazolium bromide i.e. MTT), to blue formazan particles by mitochondrial succinate dehydrogenase enzyme of intact mitochondria of living cells. Formazan was measured spectrophotometrically. Following the termination of $\mathrm{NiCl}_{2}$ exposure, the cells were stained with MTT (SigmaAldrich, St. Louis, MO, USA) at a final concentration of $0.2 \mathrm{mg} / \mathrm{ml}$. After $2 \mathrm{~h}$ incubation $\left(37^{\circ} \mathrm{C}\right.$, and $5.0 \% \mathrm{CO}_{2}$ atmosphere), the cells and the formazan crystals were dissolved in $150 \mu 1$ of acidified $(0.08 \mathrm{M} \mathrm{HCl})$ isopropanol (CentralChem, Bratislava, Slovak Republic). The absorbance was determined at a measuring wavelength of $570 \mathrm{~nm}$ against $620 \mathrm{~nm}$ as reference by a microplate reader (Anthos MultiRead 400, Austria). The data were expressed in percentage of the control group (i.e. absorbance of formazan from cells not exposed to $\mathrm{NiCl}_{2}$ ).

\section{Hormonal analysis}

At the end of $48 \mathrm{~h} \mathrm{NiCl}_{2}$ exposure, the aliquots of the culture medium were removed from the 24-well cell culture plates and after centrifugation the supernatant was collected and frozen at $-80^{\circ} \mathrm{C}$ until sexual steroid hormones measurements. Enzyme linked immunosorbent assay (ELISA) was used for the quantification of progesterone, testosterone and 17ß-estradiol (Dialab $\mathrm{GmbH}$, Wiener Neudorf, Austria) directly from the aliquots of the medium. According to the manufacturer's data, the sensitivity of testosterone assay was $0.075 \mathrm{ng} / \mathrm{ml}$, and the intra- and inter-assay coefficients of variation were $4.6 \%$ and $7.5 \%$, respectively. Crossreactivity with $5 \alpha$-dihydrotestosterone was $16.0 \%$. The sensitivity of progesterone assay was $0.05 \mathrm{ng} / \mathrm{ml}$, and the intra- and inter-assay coefficients of variation were $\leq 4.0 \%$ and $\leq 9.3 \%$, respectively. The intra- and interassay coefficients of variation for the $17 \beta$-estradiol assay were $\leq 9.0 \%$ and $\leq 10.0 \%$, and the sensitivity was $8.68 \mathrm{pg} / \mathrm{ml}$. The absorbance was determined at a wavelength $450 \mathrm{~nm}$ using a microplate reader (Anthos MultiRead 400, Austria) and the data were evaluated by WinRead 2.30 computer software. Values were expressed in percentage of the untreated control (control groups served as $100 \%$ ). Forscolin, prochloraz and aminoglutethimide (Sigma-Aldrich, St. Louis, MO, USA) dissolved in $0.1 \%$ DMSO were used as positive controls.

\section{Statistical analysis}

Obtained data were statistically analyzed using the PC program GraphPad Prism 3.02 (GraphPad Software Incorporated, San Diego, California, USA). Descriptive statistical characteristics (arithmetic mean, minimum, maximum, standard deviation and coefficient of variation) were evaluated. Homogeneity of variance was assessed by Bartlett's test. One-way analysis of variance (ANOVA) and the Dunnett's multiple comparison tests were used for statistical evaluations. The level of significance was set at $* * *(\mathrm{P}<0.001) ; * *(\mathrm{P}<0.01)$ and $*(\mathrm{P}<0.05)$. Three independent experiments were performed.

\section{Results}

\section{Cell viability}

The cell viability remained relatively unaltered up to $125 \mu \mathrm{M}(\mathrm{P}>0.05)$ and slightly decreased from $250 \mu \mathrm{M}$ of $\mathrm{NiCl}_{2}(\mathrm{P}<0.05)$. The cytotoxic effect of $\mathrm{NiCl}_{2}(<50 \%)$ was very distinct $(\mathrm{P}<0.01)$ in the group with the highest concentration (500 $\mu \mathrm{M})$ of $\mathrm{NiCl}_{2}$ (Fig. 2).

\section{Release of progesterone by human adrenocortical carcinoma (NCI-H295R) cell line}

Following $48 \mathrm{~h}$ culture of NCI-H295R cell line in the presence of $\mathrm{NiCl}_{2}$, a dose-dependent depletion $(\mathrm{P}<0.01)$ of progesterone release was observed in all the experimental groups, even at the lowest concentration $(3.90 \mu \mathrm{M})$ of $\mathrm{NiCl}_{2}$ used in the study $(19.56 \pm 4.00 \mathrm{ng} / \mathrm{ml})$. Lower levels of progesterone were detected in groups with higher doses $(\geq 125 \mu \mathrm{M})$ of $\mathrm{NiCl}_{2}(\mathrm{P}<0.01)$ as shown in Table 1. In the control group, progesterone production $(100 \%)$ was $21.05 \pm 4.40 \mathrm{ng} / \mathrm{ml}$. The percentage changes of progesterone release after $\mathrm{NiCl}_{2}$ exposure are presented in Fig. 3. 


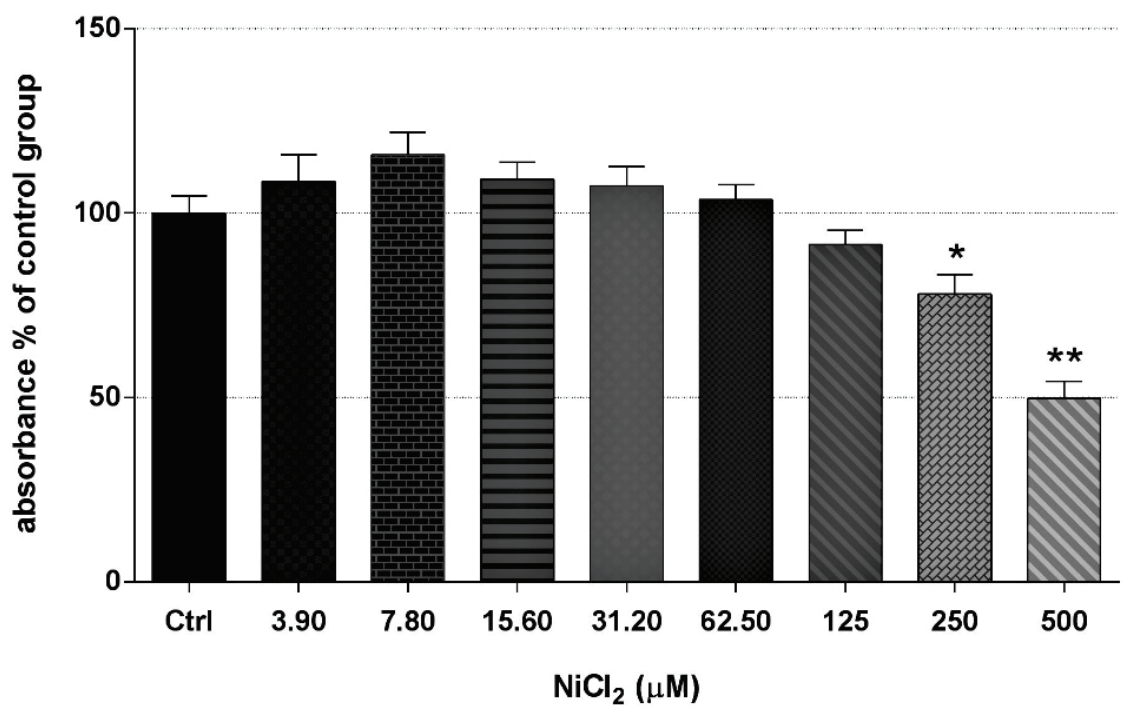

Fig. 2. The viability of NCI-H295R cell line in culture after $48 \mathrm{~h}$ of $\mathrm{NiCl}_{2}$ exposure. The cytotoxicity was assessed using the MTT assay following $\mathrm{NiCl}_{2}$ exposure. Each point represents the arithmetic mean ( \pm S.D.) absorbance in \% of (untreated) controls (Ctrl) determined in three independent experiments. The number of replicate wells was 22-32 at each point. A decline in absorbance reflects a decline in cell viability. The statistical difference between the values of $\mathrm{Ctrl}$ and treated cells was indicated by asterisks *** $(\mathrm{P}<0.001)$; ** $(\mathrm{P}<0.01)$ and $*(\mathrm{P}<0.05)$ (One-way ANOVA with Dunnett's multiple comparison test).

Table 1. Effect of $48 \mathrm{~h} \mathrm{NiCl}_{2}$ exposure on the release of progesterone $(\mathrm{ng} / \mathrm{ml})$ by human adrenocortical carcinoma (NCI-H295R) cell line.

\begin{tabular}{|c|c|c|c|c|c|c|c|c|c|}
\hline \multirow{3}{*}{ Groups } & Control & 3.90 & 7.80 & 15.60 & 31.20 & 62.50 & 125 & 250 & 500 \\
\hline & Ctrl & $\mathbf{H}$ & $\mathbf{G}$ & $\mathbf{F}$ & $\mathbf{E}$ & D & $\mathbf{C}$ & B & $\mathbf{A}$ \\
\hline & $\mathrm{NiCl}_{2}(\boldsymbol{\mu M})$ & & & & & & & & \\
\hline$X$ & 21.05 & $19.56^{* *}$ & $11.07^{* *}$ & $10.59^{* *}$ & $11.70^{* *}$ & $9.93^{* *}$ & $7.33^{* *}$ & $6.18^{* *}$ & $5.79^{* *}$ \\
\hline minimum & 15.24 & 15.64 & 6.24 & 6.84 & 8.27 & 6.88 & 5.27 & 4.25 & 3.55 \\
\hline maximum & 28.25 & 24.12 & 14.25 & 15.26 & 14.85 & 14.49 & 10.58 & 8.18 & 7.58 \\
\hline \pm S.D. & 4.40 & 4.00 & 3.26 & 3.06 & 2.65 & 3.00 & 1.99 & 1.62 & 1.35 \\
\hline$C V(\%)$ & 20.91 & 20.46 & 29.48 & 28.96 & 22.96 & 30.24 & 27.15 & 26.13 & 23.41 \\
\hline$\%$ & 100.00 & 92.92 & 52.59 & 47.51 & 55.58 & 47.19 & 34.83 & 29.37 & 27.48 \\
\hline
\end{tabular}

$\mathrm{X}$ - arithmetic mean, \pm S.D. - standard deviation, CV (\%) - coefficient of variation. The level of significance was set at $* * *(P<0.001)$, $* *(\mathrm{P}<0.01)$ and $*(\mathrm{P}<0.05)$. Ctrl - control group.

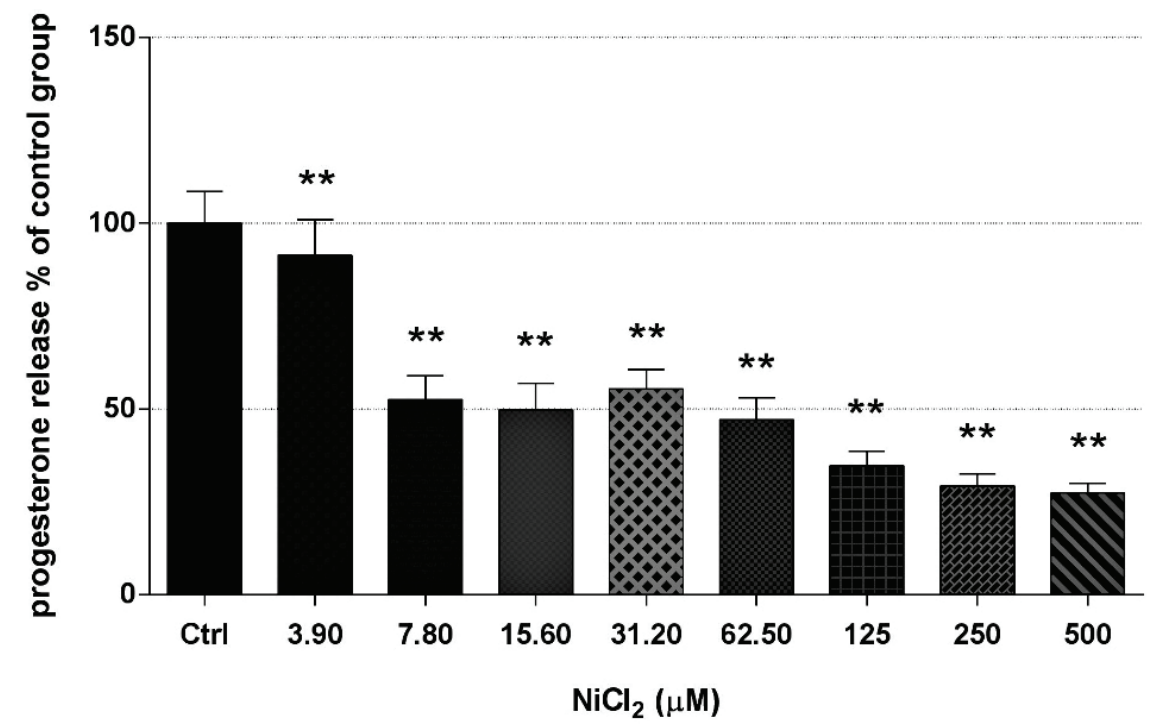

Fig. 3. Progesterone release (\%) by NCI-H295R cell line in culture after $48 \mathrm{~h}$ of $\mathrm{NiCl}_{2}$ exposure. Each point represents the arithmetic mean ( \pm S.D.) progesterone \% of (untreated) controls (Ctrl) determined of three repeated experiments. The number of replicate wells was 4-6 at each point per experiment. The statistical difference between the values of $\mathrm{Ctrl}$ and treated cells was indicated by asterisks $* * *(P<0.001)$; $* *(\mathrm{P}<0.01)$ and $*(\mathrm{P}<0.05) \quad$ (Oneway ANOVA with Dunnett's multiple comparison test). 
Release of testosterone by human adrenocortical carcinoma (NCI-H295R) cell line

Testosterone production decreased significantly $(\mathrm{P}<0.01)$ at all the concentrations of $\mathrm{NiCl}_{2}$ used in the study (Table 2). Furthermore, this decline was more prominent in comparison to that of progesterone. The lowest release of testosterone was $(\mathrm{P}<0.01)$ noted at $125 \mu \mathrm{M}$ of $\mathrm{NiCl}_{2}(1.22 \pm 0.74 \mathrm{ng} / \mathrm{ml})$ in comparison with control group $(10.75 \pm 3.45 \mathrm{ng} / \mathrm{ml})$. The percentage changes of testosterone release after $\mathrm{NiCl}_{2}$ exposure are presented in Fig. 4.

Release of 17ß-estradiol by human adrenocortical carcinoma (NCI-H295R) cell line

The $17 \beta$-estradiol production was substantially increased at low concentrations (3.90 to $62.50 \mu \mathrm{M}$ ) of $\mathrm{NiCl}_{2}$. However, the increment was not statistically significant $(\mathrm{P}>0.05)$ in comparison with control group (Fig. 5). The lowest release of 17 $\beta$-estradiol by NCI-H295R cell line was recorded in groups with high concentrations $(\geq 125 \mu \mathrm{M})$ of $\mathrm{NiCl}_{2}$, which released similar levels of $17 \beta$-estradiol (Table 3 ).

\section{Discussion}

Hormonal effects are believed to play an important role in the reproductive toxicology of $\mathrm{Ni}$ at both the neuroendocrine and gonadal levels in the hypothalamic-pituitary-gonadal (HPG) axis (Forgacs et al. 2012). The effects of $\mathrm{Ni}$ on steroidogenesis have been described recently; however, the results vary depending on the experimental model, duration of exposure as well as the doses used. The present study on the impact of $\mathrm{NiCl}_{2}$ on the NCI-H295R

Table 2. Effect of $48 \mathrm{~h} \mathrm{NiCl} 2$ exposure on the release of testosterone $(\mathrm{ng} / \mathrm{ml})$ by human adrenocortical carcinoma (NCI-H295R) cell line.

\begin{tabular}{lccccccccc}
\hline \multirow{4}{*}{ Groups } & Control & $\mathbf{3 . 9 0}$ & $\mathbf{7 . 8 0}$ & $\mathbf{1 5 . 6 0}$ & $\mathbf{3 1 . 2 0}$ & $\mathbf{6 2 . 5 0}$ & $\mathbf{1 2 5}$ & $\mathbf{2 5 0}$ & $\mathbf{5 0 0}$ \\
\cline { 2 - 9 } & $\mathbf{C t r l}$ & $\mathbf{H}$ & $\mathbf{G}$ & $\mathbf{F}$ & $\mathbf{E}$ & $\mathbf{D}$ & $\mathbf{C}$ & $\mathbf{B}$ & $\mathbf{A}$ \\
\cline { 2 - 9 } & $\mathbf{N i C l}_{\mathbf{2}}(\boldsymbol{\mu M})$ & & & & & & & & \\
\hline $\boldsymbol{X}$ & 10.75 & $4.42^{* *}$ & $3.18^{* *}$ & $1.98^{* *}$ & $4.96^{* *}$ & $1.46^{* *}$ & $1.22^{* *}$ & $2.18^{* *}$ & $1.86^{* *}$ \\
minimum & 6.54 & 2.12 & 1.84 & 0.48 & 3.02 & 0.27 & 0.25 & 0.88 & 0.57 \\
maximum & 16.44 & 7.28 & 5.87 & 3.54 & 7.12 & 2.71 & 2.33 & 3.19 & 3.21 \\
\pm S.D. & 3.45 & 2.02 & 1.47 & 1.18 & 1.71 & 0.90 & 0.74 & 0.89 & 1.07 \\
$\boldsymbol{C} \boldsymbol{V}(\%)$ & 32.12 & 45.66 & 46.33 & 59.52 & 34.45 & 61.85 & 60.43 & 41.05 & 57.51 \\
\% & 100.00 & 41.10 & 29.55 & 18.41 & 46.14 & 13.53 & 11.30 & 20.23 & 17.26 \\
\hline
\end{tabular}

$\mathrm{X}$ - arithmetic mean, \pm S.D. - standard deviation, CV (\%) - coefficient of variation. The level of significance was set at $* * *(P<0.001)$, $* *(\mathrm{P}<0.01)$ and $*(\mathrm{P}<0.05)$. Ctrl - control group.

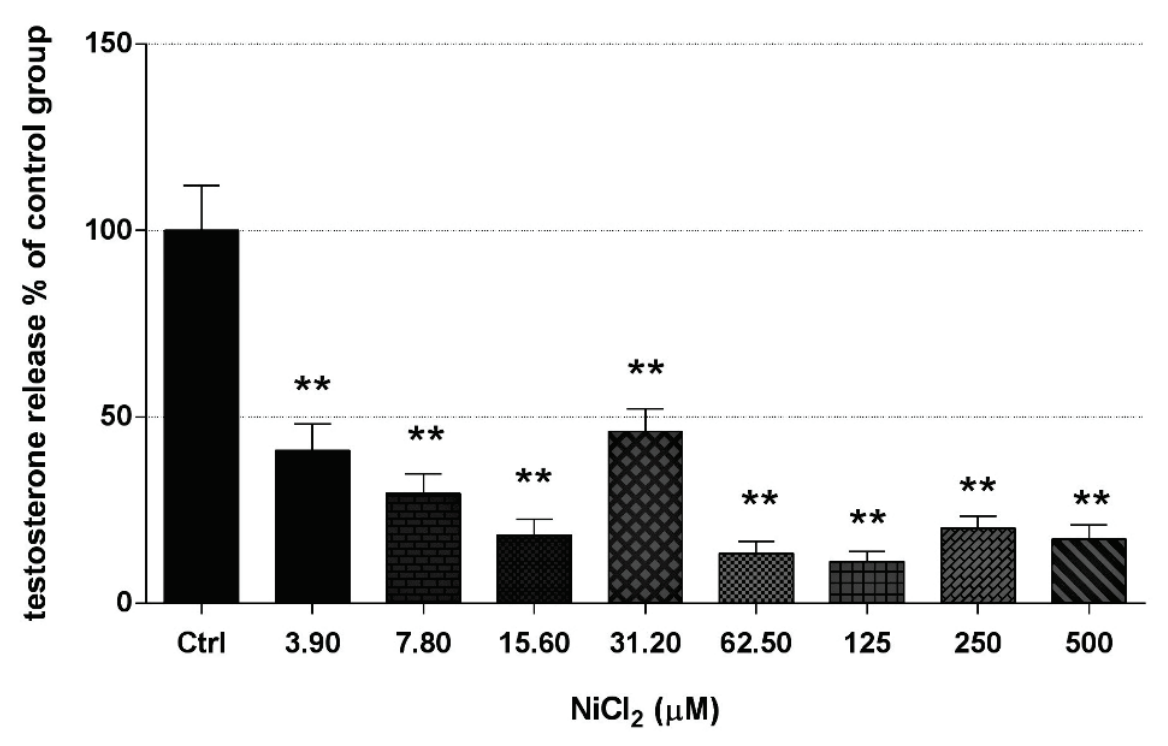

Fig. 4. Testosterone release (\%) by NCI-H295R cell line in culture after $48 \mathrm{~h}$ of $\mathrm{NiCl}_{2}$ exposure. Each point represents the arithmetic mean ( \pm S.D.) testosterone \% of (untreated) controls (Ctrl) determined of three repeated experiments. The number of replicate wells was 6-10 at each point per experiment. The statistical difference between the values of Ctrl and treated cells was indicated by asterisks $* * *(P<0.001)$; $* *(\mathrm{P}<0.01)$ and $*(\mathrm{P}<0.05)$ (Oneway ANOVA with Dunnett's multiple comparison test). 


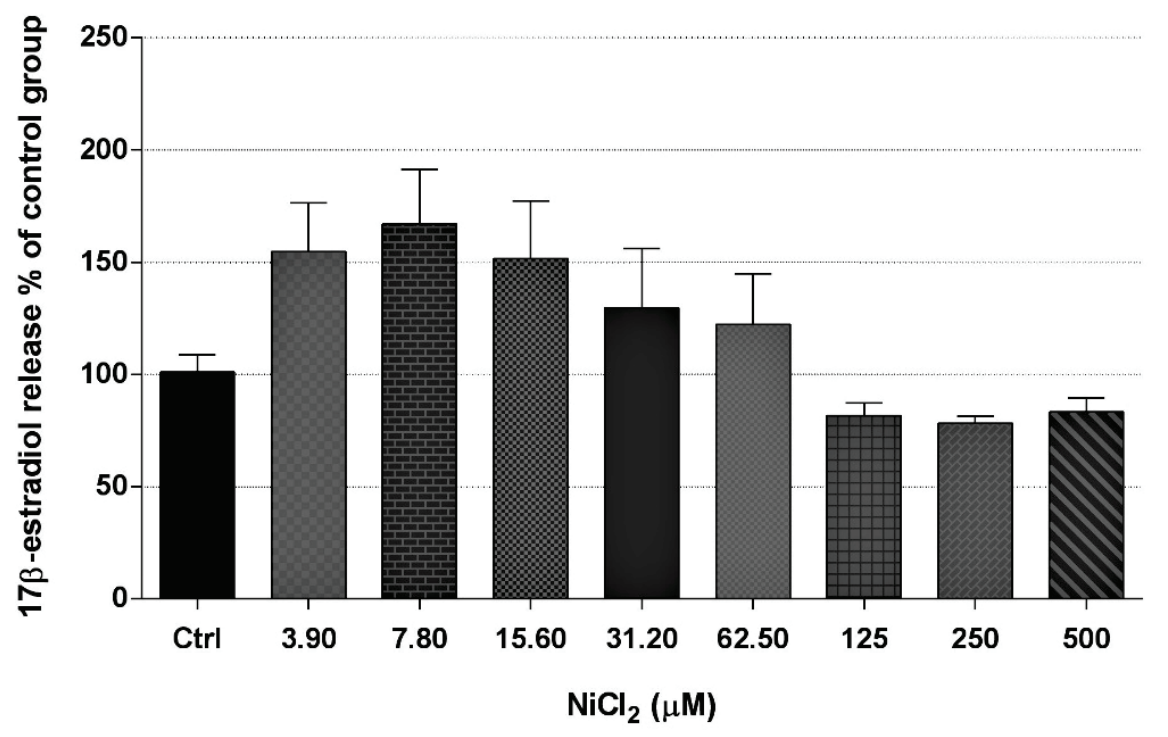

Fig. 5. $17 \beta$-estradiol release (\%) by NCI-H295R cell line in culture after $48 \mathrm{~h}$ of nickel chloride $\left(\mathrm{NiCl}_{2}\right)$ exposure. Each point represents the arithmetic mean ( \pm S.D.) $17 \beta$-estradiol \% of (untreated) controls (Ctrl) determined of three repeated experiments. The number of replicate wells was 6-12 at each point per experiment. No statistical difference between the values of $\mathrm{Ctrl}$ and treated cells was recorded $(P>0.05)$ (One-way ANOVA with Dunnett's multiple comparison test).

Table 3. Effect of $48 \mathrm{~h} \mathrm{NiCl}$ exposure on the release of $17 \beta$-estradiol $(\mathrm{pg} / \mathrm{ml})$ by human adrenocortical carcinoma (NCI-H295R) cell line.

\begin{tabular}{lccccccccc}
\hline \multirow{4}{*}{ Groups } & Control & $\mathbf{3 . 9 0}$ & $\mathbf{7 . 8 0}$ & $\mathbf{1 5 . 6 0}$ & $\mathbf{3 1 . 2 0}$ & $\mathbf{6 2 . 5 0}$ & $\mathbf{1 2 5}$ & $\mathbf{2 5 0}$ & $\mathbf{5 0 0}$ \\
\cline { 2 - 9 } & $\mathbf{C t r l}$ & $\mathbf{H}$ & $\mathbf{G}$ & $\mathbf{F}$ & $\mathbf{E}$ & $\mathbf{D}$ & $\mathbf{C}$ & $\mathbf{B}$ & $\mathbf{A}$ \\
\cline { 2 - 9 } & $\mathbf{N i C l}_{\mathbf{2}}(\boldsymbol{\mu M})$ & & & & & & & & \\
\hline $\boldsymbol{X}$ & 1.10 & 1.69 & 2.08 & 1.66 & 1.42 & 1.34 & 0.89 & 0.86 & 0.91 \\
Minimum & 0.74 & 0.94 & 1.02 & 0.80 & 0.84 & 0.94 & 0.64 & 0.76 & 0.51 \\
Maximum & 1.68 & 2.88 & 2.57 & 2.39 & 2.78 & 2.51 & 1.30 & 1.05 & 1.06 \\
$\boldsymbol{\Xi}$ S.D. & 0.29 & 0.67 & 0.57 & 0.68 & 0.71 & 0.60 & 0.20 & 0.09 & 0.18 \\
$\boldsymbol{C} \boldsymbol{V}(\%)$ & 26.32 & 39.86 & 27.57 & 41.23 & 49.90 & 45.05 & 21.87 & 10.49 & 20.35 \\
$\boldsymbol{\%}$ & 100.00 & 154.70 & 167.00 & 151.70 & 129.60 & 122.40 & 81.73 & 78.37 & 83.21 \\
\hline
\end{tabular}

$\mathrm{X}$ - arithmetic mean, \pm S.D. - standard deviation, CV (\%) - coefficient of variation. The level of significance was set at $* * *(P<0.001)$, $* *(\mathrm{P}<0.01)$ and $*(\mathrm{P}<0.05)$. Ctrl - control group.

cell line suggests a direct action of $\mathrm{NiCl}_{2}$ on the steroidproducing cells and subsequent changes in hormonal release. Nickel significantly decreased the release of progesterone and testosterone in the entire range of concentrations of $\mathrm{NiCl}_{2}$ used in the study whereas the cell viability remained relatively unaltered up to $125 \mu \mathrm{M}$ ( $P>0.05)$ and slightly decreased from $250 \mu \mathrm{M}$ of $\mathrm{NiCl}_{2}$ $(\mathrm{P}<0.05)$. The cytotoxic effect of $\mathrm{NiCl}_{2}(<50 \%)$ was evident $(\mathrm{P}<0.01)$ in the group with the highest concentration $(500 \mu \mathrm{M})$ of $\mathrm{NiCl}_{2}$. These results clearly confirm reports of Forgacs et al. (2011) and Ocztos et al. (2011), who observed similar effects of $\mathrm{Ni}^{2+}, \mathrm{Hg}^{2+}$ and $\mathrm{Cd}^{2+}$ on the release of progesterone and testosterone by NCI-H295R cell line. Using primary gonadal culture, these authors also confirmed that $\mathrm{Ni}^{2+}$ is able to disturb the sexual steroid production far below its cytotoxic concentration. Similar effects of other metals (cadmium, mercury, copper) have also been reported by our group from studies in the NCI-H295R cell line (Knazicka et al. 2013, 2015, Bilcikova et al. 2020). Earlier, Krockova and Massanyi (2010) reported a dose-dependent decrease in progesterone production by the Leydig cells at the highest concentration of $1000 \mu \mathrm{mol} / 1$ of $\mathrm{NiCl}_{2}$. Revesz et al. (2004) previously exposed human ovarian granulosa cells (obtained from women undergoing in vitro fertilization) to 15.60 to $1000 \mu \mathrm{M}$ of $\mathrm{Ni}^{2+}$ for $48 \mathrm{~h}$ in order to determine the site of action of $\mathrm{Ni}^{2+}$. The granulosa cells were stimulated to produce progesterone by using maximally stimulating amounts of human chorionic gonadotropin $(0.10 \mathrm{IU} / \mathrm{ml} \mathrm{hCG})$ or dibutyryl cyclic adenosine monophosphate (1.00 mM db-cAMP). Dosedependent depression in both hCG and db-cAMP stimulated progesterone production was seen at $15.60 \mu \mathrm{M}$ or higher concentration of $\mathrm{Ni}^{2+}$ which is not cytotoxic to 
human ovarian granulosa cells. The viability of cells remained unaffected up to $31.25 \mu \mathrm{M}$ of $\mathrm{Ni}^{2+}$ and decreased significantly at $62.50 \mu \mathrm{M}$ of $\mathrm{Ni}^{2+}$. Their data further indicated that the effect of $\mathrm{Ni}^{2+}$ on the progesterone production is not due to cytotoxicity, and the cellular site(s) of inhibitory action appears to be subsequent to the membrane receptor and production of $\mathrm{db}-\mathrm{cAMP}$. The inhibition of progesterone secretion by granulosa cells (Roychoudhury et al. 2014a, 2015) or rat ovarian fragments (Roychoudhury et al. 2014b) were also induced by other metals. The effect of $\mathrm{Ni}^{2+}$ may be associated with its interactions with other essential divalent metal cations, blocking functional groups, displacing essential metal ions or modifying active conformation of biomolecules (Coogan et al. 1989). $\mathrm{Ni}^{2+}$ is known to inhibit calcium $\left(\mathrm{Ca}^{2+}\right)$ channels. On the other hand, $\mathrm{Ca}^{2+}$ plays an important role in the regulation of progesterone production as shown in the rat granulosa cells (Tsang and Carnegie 1983). In addition, Ni has been demonstrated to alter the metabolic activity of microsomal monoxygenases, some of which are essential for steroid metabolism (Mattison et al. 1983). Thus, above mentioned findings could also participate in Ni-triggered alterations of progesterone release by NCI-H295R cell line.

Our presented data showed that testosterone seemed to be more vulnerable than progesterone and $17 \beta$-estradiol to $\mathrm{NiCl}_{2}$ exposure suggesting multiple sites of action of this metal in steroidogenesis. Disorders of the testosterone synthesis could result in a reduced activity of the key enzymes involved in the biosynthesis of testosterone. Das and Dasgupta (2002) reported that nickel sulphate $\left(\mathrm{NiSO}_{4}\right)$ affects steroidogenic enzymes

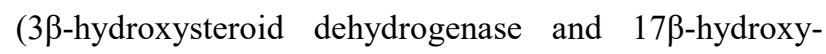
steroid dehydrogenase) causing alterations in the testosterone formation in adult rat testes. In another study, Krockova et al. (2011) investigated the effects of $\mathrm{NiCl}_{2}$ on the testosterone secretion, cell viability and apoptosis in mouse Leydig cells in vitro. They demonstrated that $\mathrm{NiCl}_{2}$ decreased the testosterone production at a low dose $(15.67 \mu \mathrm{mol} / \mathrm{l})$ and subsequently confirmed Ni-induced structural and functional alterations in the Leydig cells. Testosterone production by mouse primary Leydig cells culture following an in vitro $\mathrm{Ni}^{2+}$ exposure $(62.50$ to $1000 \mu \mathrm{M})$ was also evaluated by Forgács et al. (1998). Dose-dependent depression in hCG-stimulated testosterone production was found at $\geq 125 \mu \mathrm{M}$ or higher dose of $\mathrm{Ni}^{2+}$, while basal testosterone production remained unaffected. They further showed the effect to be dose-dependent, and is not due to cytotoxicity. Previously, Laskey and Phelps (1991) examined the effect of $\mathrm{Ni}^{2+}$ and other metal cations $\mathrm{C}^{2+}$, $\mathrm{Cu}^{2+}, \mathrm{Hg}^{2+}, \mathrm{Cd}^{2+}$ and $\left.\mathrm{Zn}^{2+}\right)$ on in vitro Leydig cell testosterone production. The results showed no change in Leydig cell viability with any metal cation treatment during the $3 \mathrm{~h}$ incubation. Dose-response depression in both hCG- and db-cAMP-stimulated testosterone production was noted with $\mathrm{Cd}^{2+}, \mathrm{Co}^{2+}, \mathrm{Cu}^{2+}, \mathrm{Hg}^{2+}$, $\mathrm{Ni}^{2+}$ and $\mathrm{Zn}^{2+}$ treatment. Surprisingly, $\mathrm{Cd}^{2+}, \mathrm{Co}^{2+}, \mathrm{Ni}^{2+}$ and $\mathrm{Zn}^{2+}$ caused a depletion in hCG- and db-cAMPstimulated testosterone production, also caused significant increases in 20 $\alpha$-hydroxycholesterol- and pregnenolone-stimulated testosterone production over untreated and similarly stimulated cultures. This indicates that these cations may act at multiple sites within the Leydig cells. Sun et al. (2003) studied the mechanisms of changes in the genital system caused by $\mathrm{NiSO}_{4}$ in male rats. They observed that the contents of testicular Ni were increased; however, the blood serum contents of testosterone, follicle-stimulating hormone (FSH) and luteinizing hormone (LH) were reduced. It was assumed that the Ni-induced genital system injury in male rats may be related to the decrease in the content of these hormones.

The present study noted that the $17 \beta$-estradiol production was increased (although non-significantly) at low concentrations ( 3.90 to $62.50 \mu \mathrm{M})$ of $\mathrm{NiCl}_{2}(\mathrm{P}>0.05)$. In agreement with our results, no significant changes were observed in serum estradiol levels in rats intraperitoneally injected with $\mathrm{NiCl}_{2}(4 \mathrm{mg} / \mathrm{kg}$ body weight) (Hfaiedh et al. 2007). In the treated rats, demonstrably increased activity of testicular aromatase was also reported. Taking into account these considerations we presume that the considerably decreased levels of testosterone together with nonsignificant alterations in release of $17 \beta$-estradiol in the present study could be associated with higher aromatase activity leading to stable estrogen levels as an adaptive response of NCI-H295R cell line to Ni exposure.

As a metalloestrogen, $\mathrm{Ni}$ activates estrogen receptor- $\alpha(E R \alpha)$ (Darbre 2006, Forgacs et al. 2012). Martin et al. (2003) examined the ability of metal ions to activate $\mathrm{ER} \alpha$ in the human breast cancer cell line (MCF-7). Similar to estradiol, treatment of cells with $\mathrm{Cu}$, $\mathrm{Co}, \mathrm{Ni}, \mathrm{Pb}, \mathrm{Hg}, \mathrm{Sn}, \mathrm{Cr}$ or V stimulated cell proliferation. The metals also decreased the concentration of ER $\alpha$ protein and mRNA, and induced expression of the estrogen-regulated genes, progesterone receptor and $\mathrm{pS} 2$. 
The ability of such metals to alter gene expression was blocked by an anti-estrogen, suggesting that their activity is probably mediated by ER $\alpha$. The estrogenic potency of Ni was comparable to that of estradiol.

Moreover, the cytotoxic effect of $\mathrm{NiCl}_{2}(<50 \%)$ was evident $(\mathrm{P}<0.01)$ in the group with the highest concentration $(500 \mu \mathrm{M} / \mathrm{ml})$ of $\mathrm{NiCl}_{2}$ used in the study. The cell viability remained relatively unaltered up to $125 \mu \mathrm{M}(\mathrm{P}>0.05)$ and slightly decreased from $250 \mu \mathrm{M}$ of $\mathrm{NiCl}_{2}(\mathrm{P}<0.05) . \mathrm{Ng}$ and Liu (1990) noted that $\mathrm{Ni}(1.0$; 10.0 and $100 \mu \mathrm{M}$ of $\left.\mathrm{NiCl}_{2} \cdot 6 \mathrm{H}_{2} \mathrm{O}\right)$ and other metals tested (including $\mathrm{PbCl}_{2}, \mathrm{ZnCl}_{2}, \mathrm{AlCl}_{3}, \mathrm{CrCl}_{3}, \mathrm{FeCl}_{2}$ and $\mathrm{LiCl}$ ) had no deleterious effect on viability and hormoneinduced steroidogenesis of Leydig cells and the cells in the adrenal gland.

\section{Conclusions}

The results of the present study indicate the endocrine disruptive effect of $\mathrm{NiCl}_{2}$ on the release of sexual steroid hormones (progesterone and testosterone) in the human adrenocortical carcinoma (NCl-H295R) cell line even at low (minimum) concentrations. Testosterone release seemed more vulnerable whereas no detrimental effect of $\mathrm{NiCl}_{2}$ could be seen at concentrations $\leq 62.50 \mu \mathrm{M}$ of $\mathrm{NiCl}_{2}$ on $17 \beta$-estradiol production thereby suggesting multiple sites of action of this metal in the steroidogenic pathway. Further research may clarify the precise molecular mechanism of action of $\mathrm{NiCl}_{2}$ on the sexual steroid production and their metabolites whose production is conditioned by the steroidogenic enzymes.

\section{Conflict of Interest}

There is no conflict of interest.

\section{Acknowledgements}

This study was financially supported by the Scientific Agency of the Slovak Republic VEGA No. 1/0163/18, APVV-15-0543, APVV-16-0289 and co-funded by European Community under project No. 26220220180: Building Research Centre, "AgroBioTech".

\section{References}

ANDERSEN HR, VINGGAARD AM, RASMUSSEN TH, GJERMANDSEN IM, BONEFELD-JORGENSEN EC: Effects of currently used pesticides in assay for estrogenicity, androgenicity and aromatase activity in vitro. Toxicol Appl Pharmacol 179: 1-12, 2002. https://doi.org/10.1006/taap.2001.9347

ANKEL-FUCHS D, THAUER RK: Nickel in biology: nickel as an essential trace element. In: The Bioorganic Chemistry of Nickel. LANCASTER JR ed. VCH Publishers Inc., New York, 1988, pp 93-110.

AGENCY FOR TOXIC SUBSTANCES AND DISEASE REGISTRY (ATSDR): Toxicological Profile for Nickel. Atlanta, GA: U.S. Department of Health and Human Services, Public Health Service, 2005.

BENSON JM, BURT DG, CARPENTER RL, EIDSON AF, HAHN FF, HALEY PJ, HANSON RL, HOBBS CH, PICKRELL JA, DUNNICK JK: Comparative inhalation toxicity of nickel sulfate to F344/N rats and B6C3F1, mice exposed for twelve days. Fundam Appl Toxicol 10: 164-178, 1988. https://doi.org/10.1093/toxsci/10.1.164

BERSENYI A, FEKETE SG, SZILAGYI M, BERTA E, ZOLDAG L, GLAVITS R: Effects of nickel supply on the fattening performance and several biochemical parameters of broiler chickens and rabbits. Acta Vet Hung 52: 185-197, 2004. https://doi.org/10.1556/avet.52.2004.2.7

BILCIKOVA J, FIALKOVA V, DURANOVA H, KOVACIKOVA E, FORGACS Z, GREN A, MASSANYI P, LUKAC N, ROYCHOUDHURY S, KNAZICKA Z: Copper affects steroidogenesis and viability of human adrenocortical carcinoma (NCI-H295R) cell line in vitro. J Environ Sci Health A Tox Hazard Subst Environ Eng: 1-8, 2020. https://doi.org/10.1080/10934529.2020.1769400

BRIX KV, KEITHLY J, DEFOREST DK, LAUGHLIN J: Acute and chronic toxicity of nickel to rainbow trout (Oncorhynchus mykiss). Environ Toxicol Chem 23: 2221-2228, 2004. https://doi.org/10.1897/03-38

CEMPEL M, NIKEL G: Nickel: A review of its sources and environmental toxicology. Polish J Environ Stud 15: 375-382, 2006.

COOGAN TP, LATTA DM, SNOW ET, COSTA M: Toxicity and carcinogenicity of nickel compounds. Crit Rev Toxicol 19: 341-384, 1989. https://doi.org/10.3109/10408448909029327

COSTA M: Molecular mechanisms of nickel carcinogenesis. Annu Rev Pharmacol Toxicol 31: 321-337, 1991. https://doi.org/10.1146/annurev.pa.31.040191.001541 
COSTA M, DAVIDSON TL, CHEN H, KE Q, ZHANG P, YAN Y, HUANG C, KLUZ T: Nickel carcinogenesis: Epigenetics and hypoxia signaling. Mutat Res 592: 79-88, 2005. https://doi.org/10.1016/j.mrfmmm.2005.06.008

DARBRE PD: Metalloestrogens: an emerging class of inorganic xenoestrogens with potential to add to the oestrogenic burden of the human breast. J Appl Toxicol 26: 191-197, 2006. https://doi.org/10.1002/jat.1135

DAS KK: A comprehensive review on nickel (II) and chromium (VI) toxicities - possible antioxidant (Allium Sativum Linn) defences. Al Ameen J Med Sci 2: 43-50, 2009.

DAS KK, DASGUPTA S: Alteration of testicular biochemistry during protein restriction in nickel treated rats. Biol Trace Elem Res 60: 243-248, 1997. https://doi.org/10.1007/bf02784444

DAS KK, DASGUPTA S: Effect of nickel on testicular nucleic acid concentrations of rats on protein restriction. Biol Trace Elem Res 73: 175-180, 2000. https://doi.org/10.1385/bter:73:2:175

DAS KK, DASGUPTA S: Effect of nickel sulfate on testicular steroidogenesis in rats during protein restriction. Environ Health Perspect 110: 923-926, 2002. https://doi.org/10.1289/ehp.02110923

DING L, MURPHY MB, HE Y, XU Y, YEUNG LWY, WANG J, ZHOU B, LAM PK, WU RS, GIESY RP: Effects of brominated flame retardants and brominated dioxins on steroidogenesis in H295R human adrenocortical carcinoma cell line. Environ Toxicol Chem 26: 764-772, 2007. https://doi.org/10.1897/06-388r1.1

EISLER R: Nickel hazards to fish, wildlife, and invertebrates: A synoptic review. Biological Science Report USGS/BRD/BSR-1998-0001. Contaminant Hazard Reviews Report 34, 1998, pp 98.

FIALKOVA V, BILCIKOVA J, KOVACIKOVA E, DURANOVA H, RYABCHENKO O, LUKAC N, KNAZICKA Z: NCI-H295R cell line as in vitro model for studying of steroidogenesis. In: Biotechnology and Quality of Raw Materials and Foodstuffs (Book of Abstracts of the XIII. International Scientific Conference). Nitra, Slovak University of Agriculture, 2018, p 33. https://doi.org/10.1080/10934529.2020.1769400

FORGÁCS Z, PAKSY K, LÁZÁR P, TÁTRAI E: Effect of Ni2+ on the testosterone production of mouse primary Leydig cell culture. J Toxicol Environ Health A 55: 213-224, 1998. https://doi.org/10.1080/009841098158502

FORGACS Z, NEMETHY Z, REVESZ C, LAZAR P: Specific amino acids moderate the effects of Ni2+ on the testosterone production of mouse Leydig cells in vitro. J Toxicol Environ Health A 62: 349-358, 2001. https://doi.org/10.1080/152873901300018075

FORGACS Z, SZIVOS-RACZ M, OCZTOS G: Study the effects of hormone disruptors on H295R cell line. (In Hungarian) Magyar Onkológia 55: 220-221, 2011.

FORGACS Z, MASSANYI P, LUKAC N, SOMOSY Z: Reproductive toxicology of nickel - Review. J Environ Sci Health A 47: 1249-1260, 2012. https://doi.org/10.1080/10934529.2012.672114

GAZDAR AF, OIE HK, SHACKLETON CH, CHEN TR, TRICHE TJ, MYERS CE, CHROUSOS GP, BRENNAN MF, STEIN CA, LA ROCCA RV: Establishment and characterization of a human adrenocortical carcinoma cell line that expresses multiple pathways of steroid biosynthesis. Cancer Res 50: 5488-5496, 1990.

GUPTA AD, PATIL AM, AMBEKAR JG, DAS SN, DHUNDASI SA, DAS KK: L-ascorbic acid protects the antioxidant defense system in nickel-exposed albino rat lung tissue. J Basic Clin Physiol Pharmacol 17: 87-100, 2006. https://doi.org/10.1515/jbcpp.2006.17.2.87

HARVEY PW, EVERETT DJ: The adrenal cortex and steroidogenesis as cellular and molecular targets for toxicity: critical omissions from regulatory endocrine disrupter screening strategies for human health. J Appl Toxicol 23: 81-87, 2003. https://doi.org/10.1002/jat.896

HECKER M, NEWSTED JL, MURPHY MB, HIGLEY EB, JONES PD, WU RSS, GIESY JP: Human adrenocarcinoma (H295R) cells for rapid in vitro determination of effects on steroidogenesis: Hormone production. Toxicol Appl Pharmacol 217: 114-124, 2006. https://doi.org/10.1016/j.taap.2006.07.007

HECKER M, GIESY JP: Novel trends in endocrine disruptor testing: the H295R steroidogenesis assay to identify inducers and inhibitors of hormone production. Anal Biochem Chem 390: 287-291, 2008. https://doi.org/10.1007/s00216-007-1657-5

HFAIEDH N, ALLAGUI MS, CROUTE F, GEURMAZI F, EL FEKI A, CARREAU S: Incidences de la restriction calorique et du Nickel sur l'aromatase testiculaire du rat. (In French) Andrologie 17: 321-328, 2007. https://doi.org/10.1007/bf03040364 
HILSCHEROVA K, JONES PD, GRACIA T, NEWSTED JL, ZHANG X, SANDERSON JT, YU RM, WU RS, GIESY JP: Assessment of the effects of chemicals on the expression of ten steroidogenic genes in the H295R cell line using real-time PCR. Toxicol Sci 81: 78-89, 2004. https://doi.org/10.1093/toxsci/kfh191

JAMBOR T, GREIFOVA H, KOVACIK A, KOVACIKOVA E, TVRDA E, FORGACS Z, MASSANYI P, LUKAC N: Parallel effect of 4-octylphenol and cyclic adenosine monophosphate (cAMP) alters steroidogenesis, cell viability and ROS production in mice Leydig cells. Chemosphere 199: 747-754, 2018. https://doi.org/10.1016/i.chemosphere.2018.02.013

JAMBOR T, KOVACIKOVA E, GREIFOVA H, KOVACIK A, LIBOVA L, LUKAC N: Assessment of the effective impact of bisphenols on mitochondrial activity and steroidogenesis in a dose-dependency in mice TM3 Leydig cells. Physiol Res 68: 689-693, 2019. https://doi.org/10.33549/physiolres.934200

KABIR ER, RAHMAN MS, RAHMAN I: A review on endocrine disruptors and their possible impacts on human health. Environ Toxicol Pharmacol 40: 241-258, 2015. https://doi.org/10.1016/j.etap.2015.06.009

KNAZICKA Z, LUKAC N, FORGACS Z, TVRDA E, LUKACOVA J, SLIVKOVA J, BINKOWSKI L, MASSANYI P: Effects of mercury on the steroidogenesis of human adrenocarcinoma (NCI-H295R) cell line. J Environ Sci Health A 48: 348-353, 2013. https://doi.org/10.1080/10934529.2013.726908

KNAZICKA Z, FORGACS Z, LUKACOVA J, ROYCHOUDHURY S, MASSANYI P, LUKAC N: Endocrine disruptive effects of cadmium on steroidogenesis: Human adrenocortical carcinoma cell line NCI-H295R as a cellular model for reproductive toxicity testing. J Environ Sci Health A 50: 348-356, 2015. https://doi.org/10.1080/10934529.2015.987520

KOLATOROVA L, DUSKOVA M, VITKU J, STARKA L: Prenatal exposure to bisphenols and parabens and impacts on human physiology. Physiol Res 66 (Suppl 3): S305-S315, 2017. https://doi.org/10.33549/physiolres.933723

KROCKOVA J, MASSANYI P: The effect of nickel on the structure and function of follicular cells and Leydig cells (In Slovak). In: In vitro cytotoxicita niklu. SUA, Nitra, 2010, pp 152.

KROCKOVA J, MASSANYI P, SIROTKIN AV, PIVKO J, MAKAREVIC AV, LUKAC N, CAPCAROVA M, TOMAN R, POLAKOVA Z: Nickel induced structural and functional alterations in mouse Leydig cells in vitro. J Trace Elem Med Biol 25: 15-18, 2011. https://doi.org/10.1016/j.jtemb.2010.11.003

LASKEY JW, PHELPS PV: Effect of cadmium and other metal cations on in vitro Leydig cell testosterone production. Toxicol Appl Pharmacol 108: 296-306, 1991. https://doi.org/10.1016/0041-008x(91)90119-y

LLAMAS A, SANZ A: Organ-distinctive changes in respiration rates of rise plants under nickel stress. Plant Growth Regul 54: 63-69, 2008. https://doi.org/10.1007/s10725-007-9229-4

LU H, SHI X, COSTA M, HUANG C: Carcinogenic effect of nickel compounds. Mol Cell Biochem 279: 45-67, 2005. https://doi.org/10.1007/s11010-005-8215-2

LUKAC N, BARDOS L, STAWARZ R, ROYCHOUDHURY S, MAKAREVICH AV, CHRENEK P, DANKO J, MASSANYI P: In vitro effect of nickel on bovine spermatozoa motility and annexin V-labeled membrane changes. J Appl Toxicol 31: 144-149, 2011. https://doi.org/10.1002/jat.1574

MATHUR AK, DATTA KK, TANDON SK, DIKSHITH TSS: Effect of nickel sulfate on male rats. Bull Environ Contam Toxicol 17: 241-248, 1977. https://doi.org/10.1007/bf01685557

MARTIN MB, REITER R, PHAM T, AVELLANET YR, CAMARA J, LAHM M, PENTECOST E, PRATAP K, GILMORE BA, DIVEKAR S, DAGATA RS, BULL JL, STOICA A: Estrogen-like activity of metals in MCF-7 breast cancer cells. Endocrinology 144: 2425-2436, 2003. https://doi.org/10.1210/en.2002-221054

MASSANYI P, TRANDZIK J, NAD P, TOMAN R, SKALICKA M, KORENEKOVA B: Seminal concentrations of trace elements in various animals and their correlations. Asian J Androl 5: 101-104, 2003.

MASSANYI P, LUKAC N, ZEMANOVA J, MAKAREVICH AV, CHRENEK P, CIGANKOVA V, FLESAROVA S, TOMAN R, FORGACS Z, SOMOSY Z, LAZOR P: Effect of nickel administration in vivo on the testicular structure in male mice. Acta Vet Brno 76: 223-229, 2007. https://doi.org/10.2754/avb200776020223

MATTISON DR, GATES AH, LEONARD A, WIDE M, HEMMINKI K, COPIUS PEEREBOOM-STEQUEMAN JHJ: Female reproductive system. In: Reproductive and Developmental Toxicity of Metals. CLARKSON TW, NORDBERG GF, SAGER PR (eds), Plenum Press, New York and London, 1983, pp 43-91. https://doi.org/10.1007/978-1-4615-9346-1 3 
MOSMANN T: Rapid colorimetric assay for cellular growth and survival: application to proliferation and cytotoxicity assays. J Immunol Methods 65: 55-63, 1983. https://doi.org/10.1016/0022-1759(83)90303-4

NG TB, LIU WK: Toxic effect of heavy metals on cells isolated from the rat adrenal and testis. In Vitro Cell Dev Biol 26: 24-28, 1990. https://doi.org/10.1007/bf02624150

OCZTOS G, FORGACS Z, SZIVOS-RACZ M: H295R Steroidogenesis assay for study endocrine disruptors and reproductive toxicants. (In Hungarian) Egészségtudomány: 55: 132-133, 2011.

OECD: H295R Steroidogenesis Assay, OECD Guideline for the Testing of Chemicals No. 456, Paris. 2011. http://www.oecd-ilibrary.org/environment/test-no-456-h295r-steroidogenesis-assay_9789264122642-en. https://doi.org/10.1787/9789264122642-en

PANDEY R, KUMAR R, SINGH SP, SAXENA DK, SRIVASTAVA SP: Male reproductive effect of nickel sulphate in mice. Biometals 12: 339-346, 1999. https://doi.org/10.1023/a:1009291816033

PANDEY R, SRIVASTAVA SP: Spermatotoxic effects of nickel in mice. Bull Environ Contam Toxicol 64: 161-167, 2000. https://doi.org/10.1007/s001289910025

PANE EF, SMITH C, MCGEER JC, WOOD CM: Mechanisms of acute and chronic waterborne nickel toxicity in the freshwater cladoceran, Daphnia magna. Environ Sci Technol 37: 4382-4389, 2003. https://doi.org/10.1021/es 0343171

PRZYBYLA AE, ROBBINS J, MENTON N, PECK HD: Structure-function relationship among the nickel-containing hydrogenases. Microbiol Rev 8: 109-135, 1992. https://doi.org/10.1111/j.1574-6968.1992.tb04960.x

RAINEY WE, SANER K, SCHIMMER BP: Adrenocortical cell lines. Mol Cell Endocrinol 228: 23-28, 2004. https://doi.org/10.1016/j.mce.2003.12.020

REVESZ C, FORGACS Z, LAZAR P, MATYAS S, RAJCZY K, KRISZA F, BERNARD A, GATI I: Effect of nickel $(\mathrm{Ni2}+)$ on primary human ovarian granulosa cells in vitro. Toxicol Mech Methods 14: 287-292, 2004. https://doi.org/10.1080/15376520490434566

RODRIGUEZ RE, MISRA M, DIWAN BA, RIGGS CW, KASPRZAK KS: Relative susceptibilities of C57BL/6X, (C57BL/6 X C3H/He)F1, and $\mathrm{C} 3 \mathrm{H} / \mathrm{He}$ mice to acute toxicity and carcinogenicity of nickel subsulfide. Toxicology 107: 131-140, 1996. https://doi.org/10.1016/0300-483x(95)03251-a

ROYCHOUDHURY S, BULLA J, SIROTKIN AV, KOLESAROVA A: In vitro changes in porcine ovarian granulosa cells induced by copper. J Environ Sci Health Part A 49: 625-633, 2014a. https://doi.org/10.1080/10934529.2014.865404

ROYCHOUDHURY S, DETVANOVA L, SIROTKIN AV, TOMAN R, KOLESAROVA A: In vitro changes in secretion activity of rat ovarian fragments induced by molybdenum. Physiol Res 63: 807-809, 2014b. https://doi.org/10.33549/physiolres.932836

ROYCHOUDHURY S, MASSANYI P, SLIVKOVA J, FORMICKI G, LUKAC N, SLAMECKA J, SLAMA P, KOLESAROVA A: Effect of mercury on porcine ovarian granulosa cells in vitro. J Environ Sci Health Part A 50: 839-845, 2015. https://doi.org/10.1080/10934529.2015.1019805

ROYCHOUDHURY S, NATH S, MASSANYI P, STAWARZ R, KACANIOVA M, KOLESAROVA A: Copperinduced changes in reproductive functions: in vivo and in vitro effects. Physiol Res 65: 11-22, 2016. https://doi.org/10.33549/physiolres.933063

SANDERSON JT, VAN DEN BERG M: Interactions of xenobiotics with the steroid hormone biosynthesis pathway. Pure Appl Chem 75: 1957-1971, 2003. https://doi.org/10.1351/pac200375111957

SANDERSON JT: The steroid hormone biosynthesis pathway as a target for endocrine-disrupting chemicals: Review. Toxicol Sci 94: 3-21, 2006. https://doi.org/10.1093/toxsci/kfl051

STAELS B, HUM DW, MILLER WL: Regulation of steroidogenesis in NCI-H295 cells: a cellular model of the human fetal adrenal. Mol Endocrinol 7: 423-433, 1993. https://doi.org/10.1210/mend.7.3.8387159

SUNDERMAN FW: Nickel. In: Elements and Their Compounds in the Environment: Occurrence, Analysis and Biological Relevance (2nd edition). MERIAN E, ANKE M, IHNAT M, STOEPPLER M (eds), WILEY - VCH Verlag GmbH \& Co. KGaA, Weinheim, 2004, pp 841-865. https://doi.org/10.1002/9783527619634

SVECHNIKOV K, LANDREH L, WEISSER J, IZZO G, COLÓN E, SVECHNIKOVA I, SÖDER O: Origin, development and regulation of human Leydig cells. Horm Res Paediatr 73: 93-101, 2010. https://doi.org/10.1159/000277141 
SUN YB, ZHU YZ, WANG XX: A study on the genital system injury induced by nickel sulfate in male rats. (In Chinese) Zhonghua Lao Dong Wei Sheng Zhi Ye Bing Za Zhi 21: 257-259, 2003.

TSANG BK, CARNEGIE JA: Calcium requirement in the gonadotropic regulation of rat granulosa cell progesterone production. Endocrinology 113: 763-769, 1983. https://doi.org/10.1210/endo-113-2-763

VITKU J, SOSVOROVA L, CHLUPACOVA T, HAMPL R, HILL M, SOBOTKA V, HERACEK J, BICIKOVA M, STARKA L: Differences in bisphenol $A$ and estrogen levels in the plasma and seminal plasma of men with different degrees of infertility. Physiol Res 64 (Suppl 2): S303-S311, 2015. https://doi.org/10.33549/physiolres.933090

YANG O, KIM HL, WEON JI, SEO YR: Endocrine-disrupting chemicals: review of toxicological mechanisms using molecular pathway analysis. J Cancer Prev 20: 12-24, 2015. https://doi.org/10.15430/jcp.2015.20.1.12

YOKIO K, UTHUS EO, NIELSEN FH: Nickel deficiency diminishes sperm quantity and movement in rats. Biol Trace Elem Res 93: 141-154, 2003. https://doi.org/10.1385/bter:93:1-3:141

YU M-H: Environmental Toxicology: Biological and Health Effects of Pollutants (2nd Edition). CRC Press LLC, Boca Raton, 2005, 368 p.

ZEMANOVA J, LUKAC N, MASSANYI P, TRANDZIK J, BUROCZIOVA M, NAD P, CAPCAROVÁ M, STAWARZ R, SKALICKA M, TOMAN R, KORENEKOVA B, JAKABOVA D: Nickel seminal concentrations in various animals and correlation to spermatozoa quality. J Vet Med A Physiol Pathol Clin Med 54: 281-286, 2007. https://doi.org/10.1111/j.1439-0442.2007.00930.x

ZHANG X, YU RMK, JONES PD, LAM GKW, NEWSTED JL, GRACIA T, HECKER M, HILSCHEROVA K, SANDERSON T, WU RS, GIESY JP: Quantitative RT-PCR methods for evaluating toxicant-induced effects on steroidogenesis using the H295R cell line. Environ Sci Technol 39: 2777-2785, 2005. https://doi.org/10.1021/es048679k 